\title{
Limited influence of stream networks on the terrestrial movements of three wetland-dependent
}

\section{frog species}

Martin J. Westgate (corresponding author), Don A. Driscoll \& David B. Lindenmayer

Fenner School of Environment and Society and the ARC Centre of Excellence for Environmental

Decisions, The Australian National University, Canberra, ACT 0200, Australia.

Email: martin.westgate@anu.edu.au

Ph: (+612) 61253729

Fax $(+612) 61250746$

Keywords: Amphibian; Anuran; Hydrological Networks; Migration; Topography

NOTICE: This is the author's version of a work that was accepted for publication in Biological

Conservation. A definitive version was subsequently published in Biological Conservation, vol 153

(September 2012), DOI: http://dx.doi.org/10.1016/j.biocon.2012.04.030 


\begin{abstract}
Quantifying functional connectivity is essential for understanding factors that limit or promote animal dispersal in fragmented landscapes. Topography is a major factor influencing the movement behaviour of many animal species, and therefore the extent of functional connectivity between habitat patches. For pond-breeding frogs, areas of low topographic relief (such as streams or drainage lines) offer damp microhabitats that can facilitate movement through otherwise dry landscapes. However, the extent of topographic bias of frog movements has rarely been quantified. We used a replicated study to compare captures in high- and low-relief transects, for three species from a pond-breeding frog community in southeastern Australia. We captured frogs significantly more often on low-relief transects. However, capture rates decreased with increasing distance from water at similar rates on both high-relief and low-relief transects, and we observed few differences between adult and juvenile movements. Our results suggest that although low-relief drainage lines are important for the pondbreeding frogs in question, ecologists and landscape managers should not discount the role of highrelief locations. Because low-relief drainage lines represent a low proportion of the pond margin, $>90 \%$ of movements are likely to occur across high-relief locations. Therefore, for the species that we studied, buffer zones designed to conserve only hydrological networks would provide insufficient protection of frequently used pond margins, while drainage lines are unlikely to act as vital networks facilitating connectivity between breeding ponds. Our study suggests that movement across slopes may be most important for facilitating functional connectivity.
\end{abstract}




\section{Introduction}

Habitat fragmentation, caused by large-scale human modification of ecosystems, is a major driver of biodiversity loss (Fahrig 2003; Kingsford et al. 2009; Lindenmayer and Fischer 2006). Conceptual landscape models which emphasize patch-matrix habitat distributions (derived from Island Biogeography Theory; MacArthur and Wilson 1967) can be useful for describing fragmented landscapes, and have therefore been influential throughout the development of landscape ecology (Haila 2002). Applications of these models commonly assume that viable metapopulations are maintained by dispersal (Hanski 1998; Leibold et al. 2004), while acknowledging that dispersal can be strongly influenced by properties of the intervening matrix (Vogt et al. 2009). Quantifying the extent to which parts of the landscape facilitate animal movement - a concept known as 'functional connectivity' (Baguette and Van Dyck 2007; Lindenmayer and Fischer 2007) - provides a basis for understanding the effects of matrix alteration on patch-dependent animal populations (see Storfer et al. 2010).

Functional connectivity is a particularly relevant concept for frog populations. Pond-breeding frogs are commonly described as a naturally occurring model of a fragmented system, because ponds appear like patches in a terrestrial matrix (Bradford et al. 2003; Marsh and Trenham 2001). For this reason, metapopulation theory (Hanski 1998) has commonly been used as a model for describing frog populations (Smith and Green 2005). However, dispersal rates are highly variable between frog species (e.g. Driscoll 1997; Smith and Green 2006), and the role of landscape resistance in explaining this variation remains unclear (Stevens et al. 2006). In particular, topographic features represent barriers to movement in some species and locations (e.g. Funk et al. 2005; Richards-Zawacki 2009; Richter-Boix et al. 2007) but not others (e.g. Davis and Roberts 2005; Driscoll 1998; Zhan et al. 2009). Functional connectivity therefore provides a framework for investigating the influence of landscape variation on frog dispersal and for deciding, in turn, which management interventions are likely to be effective for conservation (see Petranka and Holbrook 2006). 
Although there has been much research into terrestrial habitat use by frogs (Baldwin and deMaynadier 2009; Bulger et al. 2003; Parker and Anderson 2003; Patrick et al. 2008; Semlitsch and Bodie 2003), relatively little work has focused on the concept of functional connectivity at fine spatial scales (although see e.g. Popescu and Hunter 2011; Stevens et al. 2006; Todd et al. 2009). This is unusual given that conditions in the pond margin can strongly influence both landscape resistance (Semlitsch et al. 2009) and emigration orientation (Mazerolle and Vos 2006; Timm et al. 2007b), thereby inducing large differences in functional connectivity between patches at landscape scales. It is important, therefore, that investigations of landscape resistance for frogs include research into behaviour at the pond margin.

In this paper, we describe a study designed to address the question: Do frogs preferentially use areas of low topographic relief within pond margins? High-relief movement paths require more energy to cross than low relief paths (Lowe et al. 2006), and contain proportionally fewer damp microhabitats that provide refugia from desiccation (Rittenhouse et al. 2009). Further, there is evidence both that some species rely on drainage-lines to facilitate terrestrial movements (Rittenhouse and Semlitsch 2007), but also that overland dispersal can be an important process facilitating species persistence in some cases (Grant et al. 2010; Hazell et al. 2001). These examples suggest that the role of topographically defined barriers and movement corridors warrants further attention in relation to functional connectivity for frogs. However, the influence of topography on frog movements has received proportionally less attention than factors such as vegetation structure (e.g. see Semlitsch et al. 2009 and references therein).

We used a replicated, trap-based approach to quantify fine-scale variation in frog movement behaviour, taking into account several sources of variation including the effects of rainfall, migration, demography, and distance from water on capture rates, as well as topography. Our guiding assumption was that the need to avoid desiccation is an important mechanism driving spatial and temporal variability in frog terrestrial movements. Consequently, we anticipated that captures in relation to topographic relief would be influenced by both distance from water and rainfall. 
Insights into the influence of topography on frog movements are important because they have practical implications for conservation efforts. In particular, frog species with a high proportion of hydrological network-biased movement will be effectively conserved using buffer zones surrounding streams and breeding ponds (see Semlitsch and Bodie 2003), while species which predominantly display overland movements will not. More generally, our study provides a direct, replicable test of landscape resistance. Such studies are rare, but are fundamental to understanding and managing connectivity in fragmented landscapes (Fahrig 2007).

\section{Methods}

\subsection{Study area}

Our study area was Booderee National Park, in the Jervis Bay Territory, south-eastern Australia (approximate coordinates $35^{\circ} 10^{\prime} \mathrm{S} 150^{\circ} 40^{\prime} \mathrm{E}$; see Fig. 1). The park covers the majority of the southern peninsula of Jervis Bay. It is owned by the Wreck Bay Aboriginal Community, and comanaged in association with the Australian Department of Sustainability, Environment, Water, Population and Communities (SEWPaC). The study region has a temperate climate, with average annual rainfall of approximately $1200 \mathrm{~mm}$ that is largely consistent year-round. The majority of the park consists of Eucalyptus botryoides and Eucalyptus pilularis forest on deep sandy soils, but patches of woodland and coastal heath are also common, predominantly on shallow soils at higher elevations (Taws 1997).

Booderee National Park contains a number of lakes and ponds formed by the blockage of existing drainage lines by sand dunes (Jones et al. 1995). These pools provide breeding habitat for the majority of frog species in the park (Westgate et al. 2012), although some species adapted to breed in ephemeral pools in coastal heaths also occur in our study area (Penman and Brassil 2010). We chose five such ponds for this study, all of greater than five metres diameter and surrounded by eucalypt forest. All five ponds remained flooded for the duration of the investigation. At each site, we identified a single drainage line at provided the majority of inflow from runoff, although none of these contained continuously flowing water for the duration of the study period. 
The frog community in Booderee National Park consists of thirteen species split between the families Myobatrachidae (southern frogs, seven species) and Hylidae (tree frogs, six species). Both families include species that require open water for breeding (Cogger 1996). Because hylids cannot be reliably sampled using pitfall traps (Todd et al. 2007), we focused this study on Myobatrachids.

\subsection{Study design}

Our study was primarily designed to investigate variation in frog movements between high and low relief locations in pond margins. However, topography has the potential to influence movement patterns of frogs through a number of mechanisms. First, low-relief locations collect and retain moisture more effectively than high-relief locations, thereby providing more favourable microclimates for frogs. Second, vegetation structure and composition can vary across topographic gradients in riparian locations (Merrill et al. 2006). Finally, the identity and abundance of both predator and prey species vary in relation to the above processes (e.g. Camper 2009; Seagle and Sturtevant 2005). Although we attempted to control for differences in vegetation and flowing water between high and low relief transects, our study therefore tested the combined effect of a suite of co-varying topographically-dependent attributes on frog movements.

We used a replicated trapping design to investigate the occurrence of frogs in relation to three spatial variables (distance from water, topography, and direction of movement), and two temporal variables (rainfall and Julian date). Our approach provides a different interpretation from pitfall trapping studies that investigate habitat use: rather than testing whether traps in more suitable locations detect more frogs, we tested whether some traps detected a larger number of frog movements as a result of their location. Comparatively few studies have used a trapping approach to investigate frog movements (although see Timm et al. 2007b), with many authors instead using radio-tracking data to describe the behaviour of a small number of individual animals (e.g. Bulger et al. 2003; Rittenhouse and Semlitsch 2007; Sztatecsny and Schabetsberger 2005). Our approach allowed direct comparison of use of different terrestrial locations in an experimental framework. 
We established two transects at each pond, with each transect running for 200 metres from a point within $5 \mathrm{~m}$ of the waters' edge (Fig. 1). We chose $205 \mathrm{~m}$ as our maximum study distance because it was the mean minimum core terrestrial habitat area identified by Semlitsch \& Bodie (2003) in their meta-analysis of movement studies of 19 frog species. Trapping at distances shorter than $205 \mathrm{~m}$ would therefore be unjustified by the ecological literature, while larger distances were logistically unfeasible. The first transect (low-relief) at each pond followed a drainage line, with the second transect (highrelief) placed at the point on the waters' edge with the steepest slope that occurred within 90 degrees of compass orientation of the first transect. Each transect consisted of six drift fences at $40 \mathrm{~m}$ intervals, with each fence oriented parallel to the waters' edge. Fences were five metres long and had a 10 litre pitfall bucket buried on each side, with the rim positioned at ground level. These two buckets were used to differentiate between individuals moving away from water (caught on the close-to-water side of the fence), from those moving toward water. We added a 'lip' ( $\sim 5 \mathrm{~cm}$ wide) at the rim of each bucket to stop frogs from climbing out of the pitfall traps.

[Fig. 1]

In our study design, we controlled for a number of factors that had the potential to introduce confounding in the key drivers of variation in frog movement behaviour. First, we ensured that transects did not cross boundaries (either those between adjoining vegetation types, or roads or tracks), which could confound our analysis of the effect of distance from water on capture rates (Carthew et al. 2009). Second, we released all captured individuals on the opposite side of the drift fence from where they had been captured, to minimize any effect of the study design on total distance travelled. Third, we ensured that vegetation structure varied as little as possible between low-relief and high-relief transects, to avoid confounding between vegetation type and topography.

Our study design included 120 buckets $(5$ sites $\times 2$ transects $\times 6$ distance classes $\times 2$ directions), checked daily from 12th August to 17th September 2008 (37 days). This period includes the spring peak breeding season for a number of Australian frog species (Barker et al. 1995; Lemckert and Mahony 2008). We took all captured animals to a nearby field station, where we weighed them and 
took four morphological measures; snout-vent length, tibia length, head width, and internarial distance. We photographed and clipped one toe from each animal to enable individual identification, before re-releasing each animal on the opposite side of the fence at which they had been captured. We re-opened our traps at the end of summer (between 17th January and 28th February 2009; 42 days) to collect data on dispersing juveniles. During this second period, we repeated our trapping method exactly, except that recapture rates from the first trapping period (eight recaptures from 475 captures, or $<2 \%$ ) were too low for the continuation of toe clipping to be necessary or justifiable. We differentiated adults and juveniles by plotting snout-vent length against tibia length and looking for discontinuities in size (see Fig. S1). The minimum SVL measurements for adults calculated using this method were $16.0 \mathrm{~mm}$ for Crinia signifera, $22.5 \mathrm{~mm}$ for Paracrinia haswelli, and $20.0 \mathrm{~mm}$ for Uperoleia tyleri (Fig A.1).

\subsection{Statistical analysis}

We modeled occurrence of frogs in traps using Generalized Linear Mixed Models (GLMMs; Pinheiro and Bates 2000). Using GLMMs enabled us to quantify the probability of capturing an animal at each trap in relation to both spatial and temporal covariates. Since this was a trap-level analysis with low recapture rates, we excluded records of second captures of single individuals from our analysis. Sitelevel fixed effects were: distance from water $(0-200 \mathrm{~m})$, topographic relief (high or low) and direction (toward or away from water). Visit-level fixed effects were the amount of rainfall in the previous 24 hours (log-transformed) and Julian date. To account for our nested study design, and to enable us to investigate both visit-level and site-level covariates, we included five levels of nested random effects: visit (38 visits per bucket for the spring trapping period); bucket ( $\mathrm{n}=120)$; fence $(\mathrm{n}=60,10$ for each of six distance classes); transect $(\mathrm{n}=10$, five each for high- and low- topographic relief) and site $(\mathrm{n}=5)$.

Our approach to modeling these data was to create a single model that we applied to all species, enabling us to compare relative effect sizes of each covariate across species. We included all variables as additive fixed effects, plus a small number of possible interactions that we used to test for 
particular responses to spatially and temporally varying conditions. First, we tested whether frogs could move more easily along low-relief transects (interaction between distance \& transect). Second, we tested whether frogs moved further following rain (interaction between rainfall \& distance). Third, we tested whether frogs were more restricted to low-relief locations in the absence of rainfall (interaction between transect \& rainfall). Finally, we tested whether nature of the interaction between topographic relief and distance from water was affected by rainfall (i.e. a three-way interaction between these variables). Our approach was different from the more common method of choosing a 'best' model with fewer covariates; we felt that such an approach was inappropriate because of the constraints of our study design, and also because of non-trivial issues regarding the interpretation of information criteria for selection between models that include random effects (Greven and Kneib 2010; Vaida and Blanchard 2005). We used the lme4 package (Bates et al. 2011) in the R statistical program (R Core Development Team 2010) for all analyses.

To compare captures of adults versus juveniles, we used Fishers exact test to compare proportions of captures in each of four classes. Fisher's exact test works by comparing the proportion of captures from a dataset in two sets of binary categories. In each case, the first binary variable was the number of adult versus juvenile captures. In three tests for each species, we chose corresponding variables that evenly divided the total number of traps in half. These variables were simplified versions of our spatial variables of interest, i.e. topography (high versus low relief), distance from water $(0-80 \mathrm{~m}$ versus $120-200 \mathrm{~m}$ ), and direction of travel (towards or away from water). Where Fishers test gave a P value $\leq 0.05$, we took this as evidence of a significant difference in adult versus juvenile captures for the spatial comparison in question.

\subsection{Quantifying the importance of high versus low relief locations}

The final stage of our analysis was to estimate the total proportion of frogs using high or low relief landscape elements. This was important because the approach employed thus far - directly comparing frog occurrence on high-relief versus low-relief transects - implied that both transect types represent equal proportions of the pond edge, an assumption that was clearly invalid for the ponds in question. 
To quantify the relative availability of high and low relief locations, we used satellite imagery to measure the circumference of each pond, and the proportion of the circumference in each topographic class. We then multiplied the number of captures on each transect type (high or low relief) by the proportion of the pond edge in each of the respective classes. This gave us an estimate of relative frog abundance in high versus low relief locations. We then converted our estimated abundance data to percentages, and averaged the percentage of individuals using high versus low relief locations across all sites.

\section{Results}

We captured a total of 965 frogs from seven species: 538 in our spring trapping period, and 427 in our summer trapping period. However, during our spring trapping period, three species - Pseudophryne bibronii, Litoria jervisiensis and Heleioporus australiacus - were represented by only a single individual, and we captured only four adults from a fourth species (Limnodynastes peronii). This left three species that were sufficiently common to enable us to construct models of adult occurrence from our spring trapping dataset: Crinia signifera $(\mathrm{n}=171)$, Paracrinia haswelli $(\mathrm{n}=174)$ and Uperoleia tyleri $(\mathrm{n}=130)$. These three species are all small $(<50 \mathrm{~mm})$, pond-dwelling members of the family Myobatrachidae (Cogger 1996).

We found that capture probabilities decreased significantly with increasing distance from water, and increased significantly following rainfall, for all three species (Table 1). However, the effect of topography on capture rates varied between species, and was strongly mediated by both rainfall and distance from water. For C. signifera, increased captures following rainfall were concentrated on lowrelief transects $\left(\beta_{\text {(distance:transect:rain })}=0.23 \pm 0.13, \mathrm{P}=0.078\right)$. There was a similar effect for $P$. haswelli, with the majority of additional captures following rainfall occurring at short distances from water $\left(\beta_{\text {(transect.rainfall) }}=0.15 \pm 0.08, \mathrm{P}=0.067\right)$. Finally, captures of $U$. tyleri were higher on low-relief than high-relief transects after rainfall; but this pattern was reversed during drier periods (Fig. 2). Supplementary analysis of individual distance classes showed that captures were significantly higher 
on low-relief transects at distances of up to $80 \mathrm{~m}$ from water for both $C$. signifera $(\mathrm{P}=0.010)$ and $P$. haswelli $(\mathrm{P}=0.032)$ but only at the shortest distance class from water for $U$. tyleri $(\mathrm{P}=0.01)$.

[Table 1]

We found limited evidence of migratory movement in spring, with only $U$. tyleri showing evidence of higher levels of movement towards water $\left(\beta_{\text {(direction) }}=0.57 \pm 0.30, \mathrm{P}=0.061\right)$. Capture rates also increased throughout the trapping period for both $U$. tyleri $\left(\beta_{\text {(date) }}=0.11 \pm 0.01, \mathrm{P}<0.001\right)$ and $C$. signifera $\left(\beta_{(\mathrm{date})}=0.04 \pm 0.01, \mathrm{P}<0.001\right)$. Increasing captures over time in these species was not due to confounding with rainfall, since rainfall and time were poorly correlated (Pearson's correlation = 0.16), with high rainfall events occurring almost weekly throughout the study period (rainfall $>10 \mathrm{~mm}$ on days $12,18 \& 26)$.

[Fig. 2]

Results from our second trapping period (in late Summer/early Autumn) were less conclusive than those from our spring trapping period. Although we captured a reasonable number of juvenile frogs in our second trapping period $(C$. signifera $=28, P$. haswelli $=145$, U. tyleri $=32)$, most were from a single site $(\mathrm{n}=171,83 \%)$, and we did not observe any mass dispersal events. These factors limited the degree of inference that could be drawn from linear models of the kind constructed for adult captures. We therefore restricted our analysis to comparison of the proportion of adult and juvenile captures between different treatments (Table 2). Fisher's exact test showed no significant difference between adults and juveniles of any species, in terms of the proportion of individuals captured on low-relief versus high-relief transects (P values: $C$. signifera $=0.36 ; P$. haswelli $=0.45 ; U$. tyleri $=0.84)$, or with increasing distance from water (P values: C. signifera $=0.82 ; P$. haswelli $=0.19 ;$ U. tyleri $=0.79$ ). The only significant difference between adult and juvenile captures was that juvenile $P$. haswelli were significantly more likely to move away from water than were adults of the same species $(\mathrm{P}=0.006)$.

[Table 2] 
Using satellite imagery, we found that the total circumference of ponds averaged $658 \mathrm{~m}$, while low relief locations chosen for investigation in our study averaged 28 metres of the pond boundary $(<6 \%)$. This suggested that our raw data on relative numbers of captures (see Table 2) were not representative of the overall importance of high- versus low- relief locations in pond riparian margins. Although $67 \%$ of captures on average were on low-relief transects $(C$. signifera $=71 \% ; P$. haswelli $=74 \% ; U$. tyleri $=56 \%$ ), once these numbers were weighted according to the area covered by steep and shallow slopes, we found that $>90 \%$ of all animals would be likely to occur in relatively high-relief locations (C. signifera $=91 \% ;$ P. haswelli $=89 \%$; U. tyleri $=95 \%$ ).

\section{Discussion}

For this study, we aimed to quantify the extent of topographic bias in the movement behaviour of three frog species. We found that low-relief drainage lines providing the majority of inflow into breeding ponds were preferentially used by these frogs. More specifically, we found statistically significant differences in frog occurrence between high- and low- relief transects for all three species, although this effect was mediated by rainfall and distance to water (Fig. 2). While this would appear to reinforce the importance of drainage lines as priority locations for frog movements, one third of all captures were on high-relief transects, which was a higher proportion than we had expected at the outset of the study. Because drainage lines are linear features of landscapes that cover only a small proportion of pond edge, we were able to show that the absolute proportion of individuals from these three species that preferentially used low-relief locations is likely to be small.

Our finding that only a small proportion of frogs use low-relief pond margins, a pattern that was consistent for all three species for which data were available, has important implications for landscape planning and frog conservation. Some authors (e.g. Baldwin et al. 2006; Roe and Georges 2007) have suggested that reducing the radius of buffers around breeding ponds, and proportionally increasing the width of buffers centered on stream networks, would increase the representation of commonly used areas for semi-aquatic herpetofuana without increasing overall land allocation to conservation. Our results contrast with that view; a drainage-line buffer in this location would conserve areas used 
during $<10 \%$ of frog movements for the species that we studied (see also Bulger et al. 2003). Our results suggest that circular buffers around breeding ponds would be a more appropriate use of resources for the conservation of valuable terrestrial locations (see Calhoun et al. 2005; Semlitsch and Bodie 2003). Rather than conflicting with earlier research, however, these results reinforce the deeper message that empirical testing of frog movement behaviour is important to ensure that buffers meet their goals of conserving viable frog populations (Gamble et al. 2007; Goates et al. 2007).

Use of high-relief transects by frogs was unexpectedly high in our study. This is particularly surprising considering that most studies of amphibian movements in riparian areas either use fences as enclosures to capture all migrating individuals (e.g. Gibbons et al. 2006; Regosin et al. 2005), or else increase trap effort with increasing distance from water, such that a constant proportion of pond edge is represented at each distance class (e.g. Patrick et al. 2008). Such an approach was impossible in our study because drainage lines are linear features. Our methodology would therefore lead us to expect decreasing captures with distance on high-relief transects, simply as a result of lower proportional survey effort with increasing distance from water. However, if drainage lines act as movement corridors for frogs (Rittenhouse and Semlitsch 2007), we would not expect a corresponding decrease in captures on low-relief transects. We were surprised, therefore, to find that capture rates decreased at similar rates with increasing distance from water on both high-relief and low-relief transects (Fig. 2). Although this result might have eventuated by chance if frogs commonly moved parallel to the pond edge, such movement is inconsistent with perpendicular movement observed for U. tyleri. Therefore, the available evidence suggests that drainage lines are not acting as movement corridors. Instead, low-relief locations are functionally similar to high-relief transects, but with higher densities near the pond edge.

Despite our finding of decreasing occupancy of frogs with increasing distance from water (consistent with Semlitsch and Bodie 2003), some frogs used terrestrial areas at large distances from water during the breeding season. Locations up to 80 meters from water - a distance which exceeds mandated buffer zone widths in some jurisdictions (Goates et al. 2007) - had a $>20 \%$ probability of capturing $C$. signifera or U. tyleri following rainfall (Fig. 2). This finding has two important implications. First, 
buffer zones up to $80 \mathrm{~m}$ from the waters' edge may be used throughout the breeding season, most likely for foraging. Interestingly, this is lower than some estimates; for example, C. signifera can be ubiquitous at distances of up to $500 \mathrm{~m}$ from water in some locations (Lauck 2005). This reinforces the importance of comparatively large buffer zone widths (Harper et al. 2008). Second, locations $>80 \mathrm{~m}$ from water supported a smaller increase in captures following rain, suggesting that rainfall did not increase the likelihood of long-distance adult movements (i.e. migration or dispersal). Although weather can strongly influence the probability of dispersive movements in frogs (Gibbons et al. 2006; Timm et al. 2007a) as well as in other animal taxa (e.g. Walls et al. 2005), our results support the view that favorable weather conditions may not initiate migratory or dispersive movements (see also Semlitsch 2008).

Our finding that terrestrial locations were commonly used by the frog species that we studied was exemplified by one species in particular. High captures of Uperoleia tyleri in high-relief and long distance-from-water locations might have been influenced by high levels of territoriality among male U. tyleri (Robertson 1986). This is because territoriality could mitigate against concentration of individuals in locations with favourable microhabitat characteristics. More importantly, however, $U$. tyleri was the only species for which there was evidence of migratory behaviour during our spring trapping period. This evidence included an initial absence of captures for this species (first capture on day 10), and some directional movement $\left(\beta_{\text {(direction) }}=0.57 \pm 0.30, \mathrm{P}=0.061\right)$. The fact that we found no corresponding evidence of topographically-biased movement for this species suggests that $U$. tyleri uses high-relief locations during migration and/or dispersal. These findings support our assertion that high-relief locations are likely to be important for ongoing persistence of local breeding populations for this species (see Harper et al. 2008).

We found no evidence for a difference in terrestrial movements between adults and juveniles of any species. The only exception was that directional movement of juveniles was greater than for adults in P. haswelli (Table 1). This difference was expected given that metamorphic juveniles must begin their movements from water (and can therefore only move away from their natal ponds), whereas adults may occur at a range of distances from water at the beginning of their migratory period. While these 
results may appear surprising given that juveniles are commonly thought to be the dispersive phase in the frog life cycle (Semlitsch 2008), contrary evidence does exist for some species. Smith and Green (2006), for example, report that movements of Fowler's Toads (Bufo fowleri) are not demographically biased. Given the importance of juvenile dispersal for predicting demographic variation and the persistence of frog populations (Swanack et al. 2009), juvenile-biased dispersal should be carefully tested for, rather than assumed, in frog species.

To what extent are our results relevant for describing functional connectivity across landscapes? The answer to this question depends upon the extent to which our results are representative of dispersive movements for the species in question. Although there are prominent examples where frogs have made long-distance directed movements toward breeding sites (Sjogren-Gulve 1998), there is also evidence of frog species following undirected movement paths (Rothermel 2004; Schwarzkopf and Alford 2002). In the latter case, dispersal would result from a series of small foraging movements, rather than being a deliberate behaviour (Hawkes 2009; Van Dyck and Baguette 2005). Even if foraging and dispersal are different behaviours, we are unaware of any evidence suggesting that topographic bias in frog movements varies between foraging and dispersal. In this case, our finding of limited differences between adult and juvenile behaviour (Table 2) supports the argument that our results are representative of general movement behaviour for the species in question. The available evidence therefore suggests that strong topographically-biased dispersal is unlikely at landscape scales for the species that we studied. This also implies that isolation of breeding ponds will predominantly be influenced by distance rather than topography, decreasing pond isolation, and thereby reducing the probability of local extinction (Griffen and Drake 2009; Johst et al. 2011). However, studies at larger spatial scales would be necessary to confirm these expectations (Hovestadt et al. 2011; Jacobson and Peres-Neto 2010).

\section{Conclusions}

Our study has shown that - for the pond-breeding frogs that we examined - the majority of individuals used terrestrial areas that were not located on drainage lines. This leads to two important 
conclusions for frog conservation in this location. First, buffer zones designed to conserve only hydrological networks would provide insufficient protection of locations that were commonly used by frogs in this study. Second, drainage lines are unlikely to be vital networks facilitating connectivity between breeding ponds for the species that we studied. Underlying these unexpected responses to topography were a series of unexpected movement behaviours in the frog species in question. These included: (1) near-continuous use of terrestrial areas at large distances (up to 80 metres) from water during the breeding season. (2) Low incidence of directional or migratory movement. (3) Limited differences between adult and juvenile movements. Focusing on the nexus between fine-scale movement behavior and landscape scale connectivity has therefore provided novel insights into behaviors which underlie variation in terrestrial movement behaviour by frogs in this location. However, further work is required to determine the extent to which the patterns we have identified apply more generally. In particular, larger frogs are generally capable of dispersing with low risk of dehydration (Tracy et al. 2010), while frogs that are closely related, but ecologically dissimilar, may use terrestrial locations in different ways (Rowley and Alford 2007; Tracy et al. 2010). Along with identification and prioritization of at-risk habitats (Baldwin and deMaynadier 2009), anchoring estimates of functional connectivity in an understanding of animal behavior at relevant spatial scales (Van Dyck and Baguette 2005) is therefore an important goal for amphibian conservation in future.

\section{Acknowledgements}

This research was greatly improved by support and advice from C. MacGregor, by discussion with T. Penman, and by comments from three anonymous reviewers. The authors wish to thank the people of Wreck Bay Aboriginal Community, on whose land this research was conducted. This work would not have been possible without the assistance and support of staff at Booderee National Park, particularly N. Dexter \& M. Hudson. Data collection methods were approved by the ANU Animal Experimentation Ethics Committee, permit number C.RE.50.08. This work was supported by funding from the ACT Herpetological Association (ACTHA) and the ANU Vice-Chancellors' Fieldwork Grants scheme. 


\section{References}

Baguette, M., Van Dyck, H., 2007. Landscape connectivity and animal behavior: functional grain as a key determinant for dispersal. Landscape Ecology 22, 1117-1129.

Baldwin, R.F., Calhoun, A.J.K., deMaynadier, P.G., 2006. Conservation planning for amphibian species with complex habitat requirements: A case study using movements and habitat selection of the Wood Frog Rana sylvatica. Journal of Herpetology 40, 442-453.

Baldwin, R.F., deMaynadier, P.G., 2009. Assessing threats to pool-breeding amphibian habitat in an urbanizing landscape. Biological Conservation 142, 1628-1638.

Barker, J., Grigg, G.C., Tyler, M.J., 1995. A Field Guide to Australian Frogs. Surrey Beatty and Sons, Chipping Norton.

Bates, D., Maechler, M., Bolker, B., 2011. lme4: Linear mixed-effects models using S4 classes. R package version 0.99937542 http://CRAN.R-project.org/package=lme4

Bradford, D.F., Neale, A.C., Nash, M.S., Sada, D.W., Jaeger, J.R., 2003. Habitat patch occupancy by toads (Bufo punctatus) in a naturally fragmented desert landscape. Ecology 84, 1012-1023.

Bulger, J.B., Scott Jr, N.J., Seymour, R.B., 2003. Terrestrial activity and conservation of adult California red-legged frogs Rana aurora draytonii in coastal forests and grasslands. Biological Conservation 110, 85-95.

Calhoun, A.J.K., Miller, N.A., Klemens, M.W., 2005. Conserving pool-breeding amphibians in human-dominated landscapes through local implementation of Best Development Practices. Wetlands Ecology and Management 13, 291-304.

Camper, J.D., 2009. Core Terrestrial Habitat Around Wetlands: Contributions from the Spatial Ecology of the Redbelly Watersnake (Nerodia erythrogaster erythrogaster). Copeia, 556-562.

Carthew, S.M., Horner, B., Jones, K.M.W., 2009. Do utility corridors affect movements of small terrestrial fauna? Wildlife Research 36, 488-495.

Cogger, H.G., 1996. Reptiles and Amphibians of Australia. Reed Publishers.

Davis, R.A., Roberts, J.D., 2005. Population genetic structure of the western spotted frog, Heleioporus albopunctatus (Anura: Myobatrachidae), in a fragmented landscape in south-western Australia. Australian Journal of Zoology 53, 167-175.

Driscoll, D.A., 1997. Mobility and metapopulation structure of Geocrinia alba and Geocrinia vitellina, two endangered frog species from southwestern Australia. Australian Journal of Ecology 22, 185-195.

Driscoll, D.A., 1998. Genetic Structure of the Frogs Geocrinia lutea and Geocrinia rosea Reflects Extreme Population Divergence and Range Changes, Not Dispersal Barriers. Evolution 52, 1147 1157.

Fahrig, L., 2003. Effects of habitat fragmentation on biodiversity. Annual Review of Ecology Evolution and Systematics 34, 487-515.

Fahrig, L., 2007. Non-optimal animal movement in human-altered landscapes. Functional Ecology 21, 1003-1015. 
Funk, W.C., Blouin, M.S., Corn, P.S., Maxell, B.A., Pilliod, D.S., Amish, S., Allendorf, F.W., 2005. Population structure of Columbia spotted frogs (Rana luteiventris) is strongly affected by the landscape. Molecular Ecology 14, 483-496.

Gamble, L.R., McGarigal, K., Compton, B.W., 2007. Fidelity and dispersal in the pond-breeding Ambystoma opacum: Implications for spatio-temporal population dynamics and conservation. Biological Conservation 139, 247-257.

Gibbons, J.W., Winne, C.T., Scott, D.E., Willson, J.D., Glaudas, X., Andrews, K.M., Todd, B.D., Fedewa, L.A., Wilkinson, L., Tsaliagos, R.N., Harper, S.J., Greene, J.L., Tuberville, T.D., Metts, B.S., Dorcas, M.E., Nestor, J.P., Young, C.A., Akre, T., Reed, R.N., Buhlman, K., 2006. Remarkable amphibian biomass and abundance in an isolated wetland: implications for wetland conservation. Conservation Biology 20, 1457-1465.

Goates, M.C., Hatch, K.A., Eggett, D.L., 2007. The need to ground truth $30.5 \mathrm{~m}$ buffers: A case study of the boreal toad (Bufo boreas). Biological Conservation 138, 474-483.

Grant, E.H.C., Nichols, J.D., Lowe, W.H., Fagan, W.F., 2010. Use of multiple dispersal pathways facilitates amphibian persistence in stream networks. Proceedings of the National Academy of Sciences of the United States of America 107, 6936-6940.

Greven, S., Kneib, T., 2010. On the behaviour of marginal and conditional AIC in linear mixed models. Biometrika 97, 773-789.

Griffen, B.D., Drake, J.M., 2009. Environment, but not migration rate, influences extinction risk in experimental metapopulations. Proceedings of the Royal Society B-Biological Sciences 276, 43634371.

Haila, Y., 2002. A conceptual geneology of fragmentation research: from island biogeography to landscape ecology. Ecological Applications 12, 321-334.

Hanski, I., 1998. Metapopulation Dynamics. Nature 396, 41-49.

Harper, E.B., Rittenhouse, T.A.G., Semlitsch, R.D., 2008. Demographic consequences of terrestrial habitat loss for pool-breeding amphibians: Predicting extinction risks associated with inadequate size of buffer zones. Conservation Biology 22, 1205-1215.

Hawkes, C., 2009. Linking movement behaviour, dispersal and population processes: is individual variation a key? Journal of Animal Ecology 78, 894-906.

Hazell, D., Cunningham, R., Lindenmayer, D.B., Mackey, B., Osborne, W., 2001. Use of farm dams as frog habitat in an Australian agricultural landscape: factors affecting species richness and distribution. Biological Conservation 102, 155-169.

Hovestadt, T., Binzenhoefer, B., Nowicki, P., Settele, J., 2011. Do all inter-patch movements represent dispersal? A mixed kernel study of butterfly mobility in fragmented landscapes. Journal of Animal Ecology 80, 1070-1077.

Jacobson, B., Peres-Neto, P.R., 2010. Quantifying and disentangling dispersal in metacommunities: how close have we come? How far is there to go? Landscape Ecology 25, 495-507.

Johst, K., Drechsler, M., van Teeffelen, A.J.A., Hartig, F., Vos, C.C., Wissel, S., Waetzold, F., Opdam, P., 2011. Biodiversity conservation in dynamic landscapes: trade-offs between number, connectivity and turnover of habitat patches. Journal of Applied Ecology 48, 1227-1235. 
Jones, N., Abell, R., Jacobson, G., 1995. Hydrology, In Jervis Bay: a place of cultural, scientific and educational value. eds G. Cho, A. Georges, R. Stoutjesdijk, R. Longmore, pp. 53-64. Australian Nature Conservation Agency, Canberra.

Kingsford, R.T., Watson, J.E.M., Lundquist, C.J., Venter, O., Hughes, L., Johnston, E.L., Atherton, J., Gawel, M., Keith, D.A., Mackey, B.G., Morley, C., Possingham, H.P., Raynor, B., Recher, H.F., Wilson, K.A., 2009. Major Conservation Policy Issues for Biodiversity in Oceania. Conservation Biology 23, 834-840.

Lauck, B., 2005. The impact of recent logging and pond isolation on pond colonization by the frog Crinia signifera. Pacific Conservation Biology 111, 50-60.

Leibold, M.A., Holyoak, M., Mouquet, N., Amarasekare, P., Chase, J.M., Hoopes, M.F., Holt, R.D., Shurin, J.B., Law, R., Tilman, D., Loreau, M., Gonzalez, A., 2004. The metacommunity concept: a framework for multi-scale community ecology. Ecology Letters 7, 601-613.

Lemckert, F., Mahony, M., 2008. Core calling periods of the frogs of temperate New South Wales, Australia. Herpetological Conservation and Biology 3, 71-76.

Lindenmayer, D.B., Fischer, J., 2006. Habitat fragmentation and landscape change. Island Press, Washington.

Lindenmayer, D.B., Fischer, J., 2007. Tackling the habitat fragmentation panchreston. Trends in Ecology and Evolution 22, 127-132.

Lowe, W.H., Likens, G.E., McPeek, M.A., Buso, D.C., 2006. Linking direct and indirect data on dispersal: Isolation by slope in a headwater stream salamander. Ecology 87, 334-339.

MacArthur, R.H., Wilson, E.O., 1967. The theory of island biogeography. Princeton University Press.

Marsh, D.M., Trenham, P.C., 2001. Metapopulation dynamics and amphibian conservation.

Conservation Biology 15, 40-49.

Mazerolle, M.J., Vos, C.C., 2006. Choosing the safest route: Frog orientation in an agricultural landscape. Journal of Herpetology 40, 435-441.

Merrill, A.G., Benning, T.L., Fites, J.A., 2006. Factors controlling structural and florisitic variation of riparian zones in a mountainous landscape of the western United States. Western North American Naturalist 66, 137-154.

Parker, J.M., Anderson, S.H., 2003. Habitat use and movements of repatriated Wyoming toads. Journal of Wildlife Management 67, 439-446.

Patrick, D.A., Harper, E.B., Hunter, M.L., Calhoun, A.J.K., 2008. Terrestrial habitat selection and strong density-dependent mortality in recently metamorphosed amphibians. Ecology 89, 2563-2574.

Penman, T.D., Brassil, T.E., 2010. Management of amphibian populations in Booderee National Park, South-eastern Australia. Herpetological Conservation and Biology 5, 73-79.

Petranka, J.W., Holbrook, C.T., 2006. Wetland restoration for amphibians: Should local sites be designed to support metapopulations or patchy populations? Restoration Ecology 14, 404-411.

Pinheiro, J.C., Bates, D.M., 2000. Mixed-effects models in S and S-PLUS. Springer. 
Popescu, V.D., Hunter, M.L., Jr., 2011. Clear-cutting affects habitat connectivity for a forest amphibian by decreasing permeability to juvenile movements. Ecological Applications 21, 1283 1295.

R Core Development Team, 2010. R: A Language and Environment for Statistical Computing, Version 2.11.1. R Foundation for Statistical Computing, Vienna, Austria.

Regosin, J.V., Windmiller, B.S., Homan, R.N., Reed, J.M., 2005. Variation in terrestrial habitat use by four pool-breeding amphibian species. Journal of Wildlife Management 69, 1481-1493.

Richards-Zawacki, C.L., 2009. Effects of slope and riparian habitat connectivity on gene flow in an endangered Panamanian frog, Atelopus varius. Diversity and Distributions 15, 796-806.

Richter-Boix, A., Llorente, G.A., Montori, A., 2007. Structure and dynamics of an amphibian metacommunity in two regions. Journal of Animal Ecology 76, 607-618.

Rittenhouse, T.A.G., Semlitsch, R.D., 2007. Post-breeding habitat use of wood frogs in a missouri oak-hickory forest. Journal of Herpetology 41, 645-653.

Rittenhouse, T.A.G., Semlitsch, R.D., Thompson, F.R., 2009. Survival costs associated with wood frog breeding migrations: effects of timber harvest and drought. Ecology 90, 1620-1630.

Robertson, J.G.M., 1986. Male territoriality, fighting and assessment of fighting ability in the Australian frog Uperoleia rugosa. Animal Behaviour 34, 763-772.

Roe, J.H., Georges, A., 2007. Heterogeneous wetland complexes, buffer zones, and travel corridors: Landscape management for freshwater reptiles. Biological Conservation 135, 67-76.

Rothermel, B.B., 2004. Migratory success of juveniles: a potential constraint on connectivity for pond-breeding amphibians. Ecological Applications 14, 1535-1546.

Rowley, J.J.L., Alford, R.A., 2007. Movement patterns and habitat use of rainforest stream frogs in northern Queensland, Australia: implications for extinction vulnerability. Wildlife Research 34, 371378.

Schwarzkopf, L., Alford, R.A., 2002. Nomadic movement in tropical toads. Oikos 96, 492-506.

Seagle, S.W., Sturtevant, B.R., 2005. Forest productivity predicts invertebrate biomass and ovenbird (Seiurus aurocapillus) reproduction in Appalachian landscapes. Ecology 86, 1531-1539.

Semlitsch, R.D., 2008. Differentiating migration and dispersal processes for pond-breeding amphibians. Journal of Wildlife Management 72, 260-267.

Semlitsch, R.D., Bodie, J.R., 2003. Biological criteria for buffer zones around wetlands and riparian habitats for amphibians and reptiles. Conservation Biology 17, 1219-1228.

Semlitsch, R.D., Todd, B.D., Blomquist, S.M., Calhoun, A.J.K., Gibbons, J.W., Gibbs, J.P., Graeter, G.J., Harper, E.B., Hocking, D.J., Hunter, M.L., Jr., Patrick, D.A., Rittenhouse, T.A.G., Rothermel, B.B., 2009. Effects of Timber Harvest on Amphibian Populations: Understanding Mechanisms from Forest Experiments. Bioscience 59, 853-862.

Sjogren-Gulve, P., 1998. Spatial movement patterns in frogs: Target-oriented dispersal in the pool frog, Rana lessonae. Ecoscience 5, 31-38.

Smith, M.A., Green, D.M., 2005. Dispersal and the metapopulation paradigm in amphibian ecology and conservation: are all amphibian populations metapopulations? Ecography 28, 110-128. 
Smith, M.A., Green, D.M., 2006. Sex, isolation and fidelity: unbiased long-distance dispersal in a terrestrial amphibian. Ecography 29, 649-658.

Stevens, V.M., Leboulenge, E., Wesselingh, R.A., Baguette, M., 2006. Quantifying functional connectivity: experimental assessment of boundary permeability for the natterjack toad (Bufo calamita). Oecologia 150, 161-171.

Storfer, A., Murphy, M.A., Spear, S.F., Holderegger, R., Waits, L.P., 2010. Landscape genetics: where are we now? Molecular Ecology 19, 3496-3514.

Swanack, T.M., Grant, W.E., Forstner, M.R.J., 2009. Projecting population trends of endangered amphibian species in the face of uncertainty: A pattern-oriented approach. Ecological Modelling 220, 148-159.

Sztatecsny, M., Schabetsberger, R., 2005. Into thin air: vertical migration, body condition, and quality of terrestrial habitats of alpine common toads, Bufo bufo. Canadian Journal of Zoology 83, 788-796.

Taws, N., 1997. Vegetation Survey and Mapping of Jervis Bay Territory: A report to Environment Australia. Taws Botanical Research, Canberra.

Timm, B.C., McGarigal, K., Compton, B.W., 2007a. Timing of large movement events of pondbreeding amphibians in Western Massachusetts, USA. Biological Conservation 136, 442-454.

Timm, B.C., McGarigal, K., Jenkins, C.L., 2007b. Emigration orientation of juvenile pond-breeding amphibians in Western Massachusetts. Copeia, 685-698.

Todd, B.D., Luhring, T.M., Rothermel, B.B., Gibbons, J.W., 2009. Effects of forest removal on amphibian migrations: implications for habitat and landscape connectivity. Journal of Applied Ecology 46, 554-561.

Todd, B.D., Winne, C.T., Willson, J.D., Gibbons, J.W., 2007. Getting the drift: Examining the effects of timing, trap type and taxon on herpetofaunal drift fence surveys. American Midland Naturalist 158, 292-305.

Tracy, C.R., Christian, K.A., Tracy, C.R., 2010. Not just small, wet, and cold: effects of body size and skin resistance on thermoregulation and arboreality of frogs. Ecology 91, 1477-1484.

Vaida, F., Blanchard, S., 2005. Conditional Akaike information for mixed-effects models. Biometrika 92, 351-370.

Van Dyck, H., Baguette, M., 2005. Dispersal behaviour in fragmented landscapes: Routine or special movements? Basic and Applied Ecology 6, 535-545.

Vogt, P., Ferrari, J.R., Lookingbill, T.R., Gardner, R.H., Ritters, K.H., Ostapowicz, K., 2009. Mapping functional connectivity. Ecological Indicators 9, 64-71.

Walls, S.S., Kenward, R.E., Holloway, G.J., 2005. Weather to disperse? Evidence that climatic conditions influence vertebrate dispersal. Journal of Animal Ecology 74, 190-197.

Westgate, M.J., Driscoll, D.A., Lindenmayer, D.B., 2012. Can the intermediate disturbance hypothesis and information on species traits predict amphibian responses to fire? Oikos.

Zhan, A.B., Li, C., Fu, J.Z., 2009. Big mountains but small barriers: Population genetic structure of the Chinese wood frog (Rana chensinensis) in the Tsinling and Daba Mountain region of northern China. Bmc Genetics 10. 


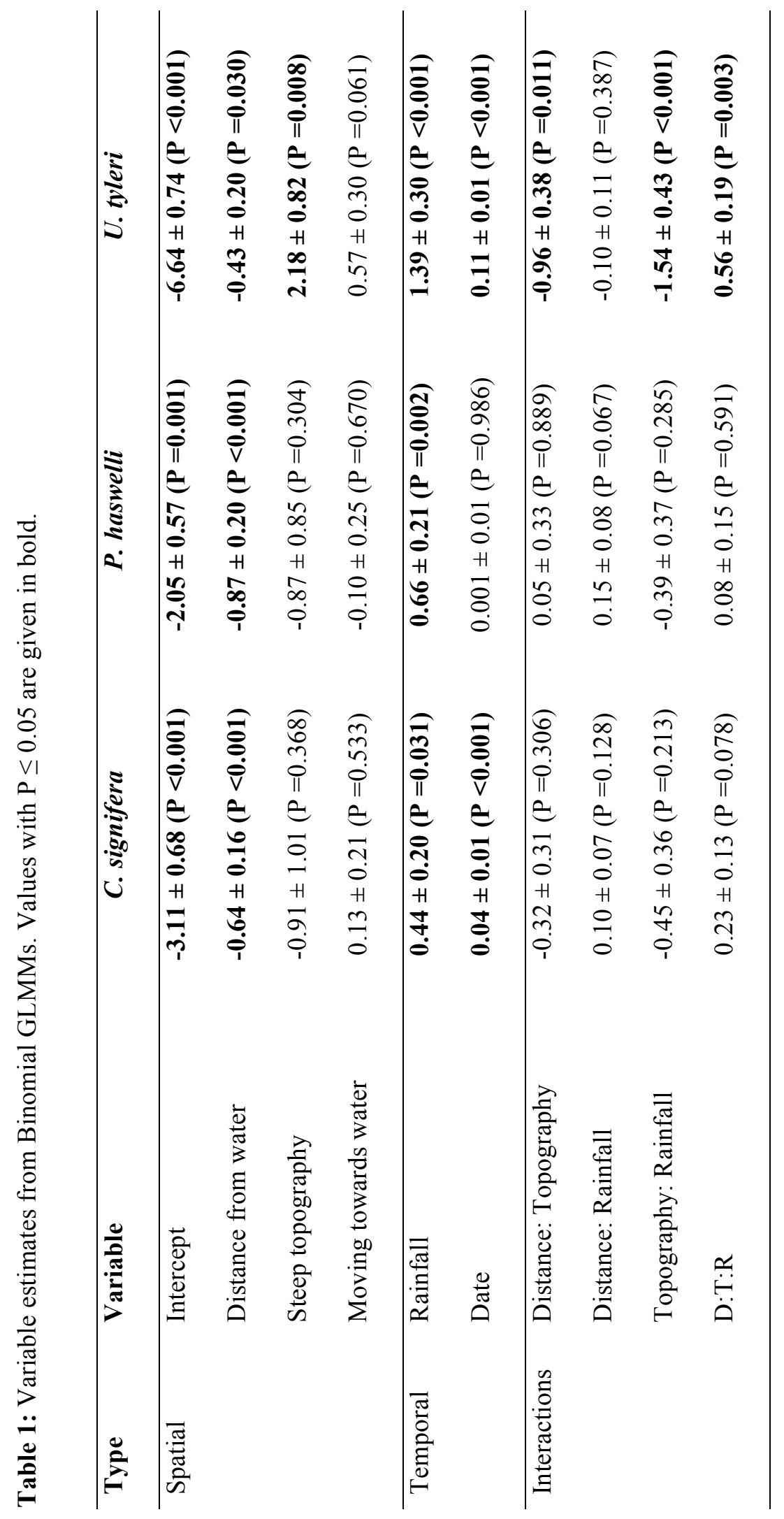




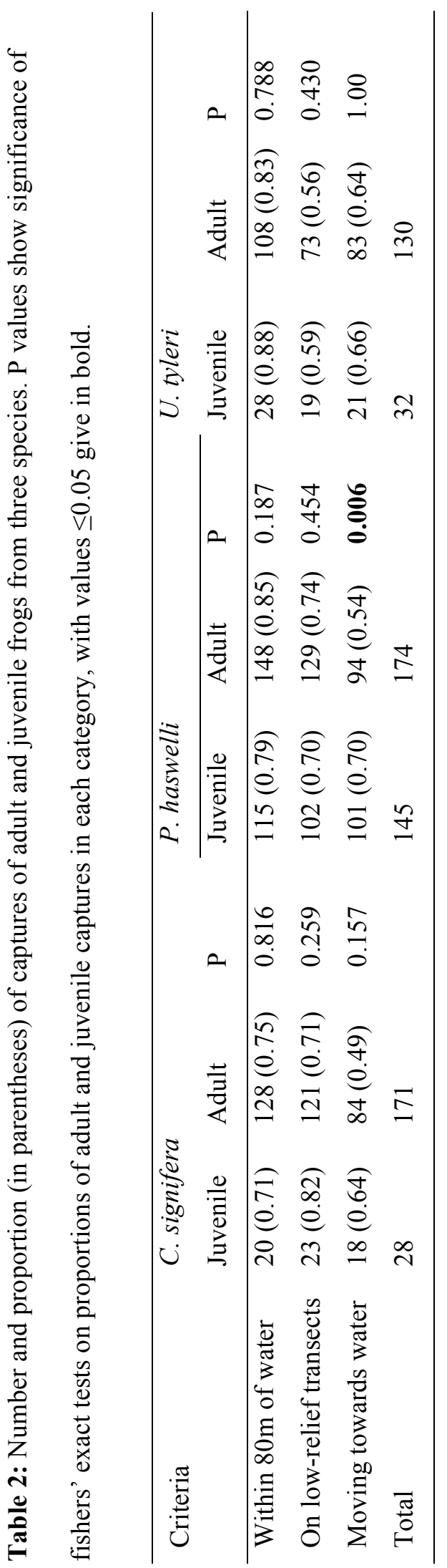


Fig. 1: Map of the study area, showing a schematic of the trapping design.

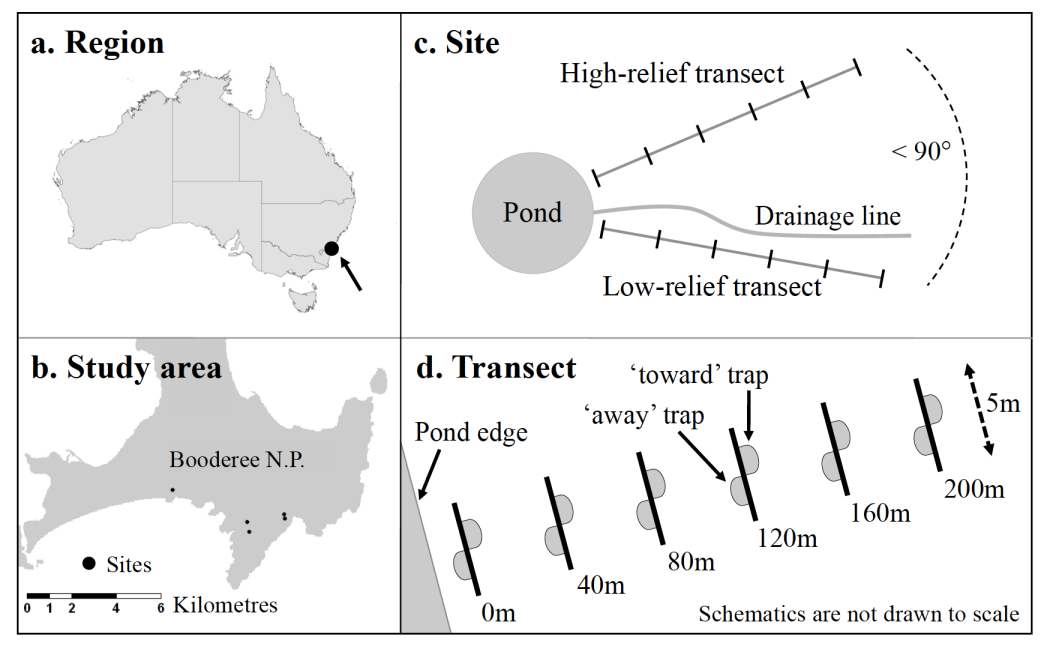

Fig. 2: Probability of occurrence with increasing distance from water, as given by GLMMs. Columns give results for each species, while rows give results for different amounts of rainfall. Solid lines (filled squares) give estimates for low-relief transects; dashed lines (open circles) give estimates for high-relief transects.
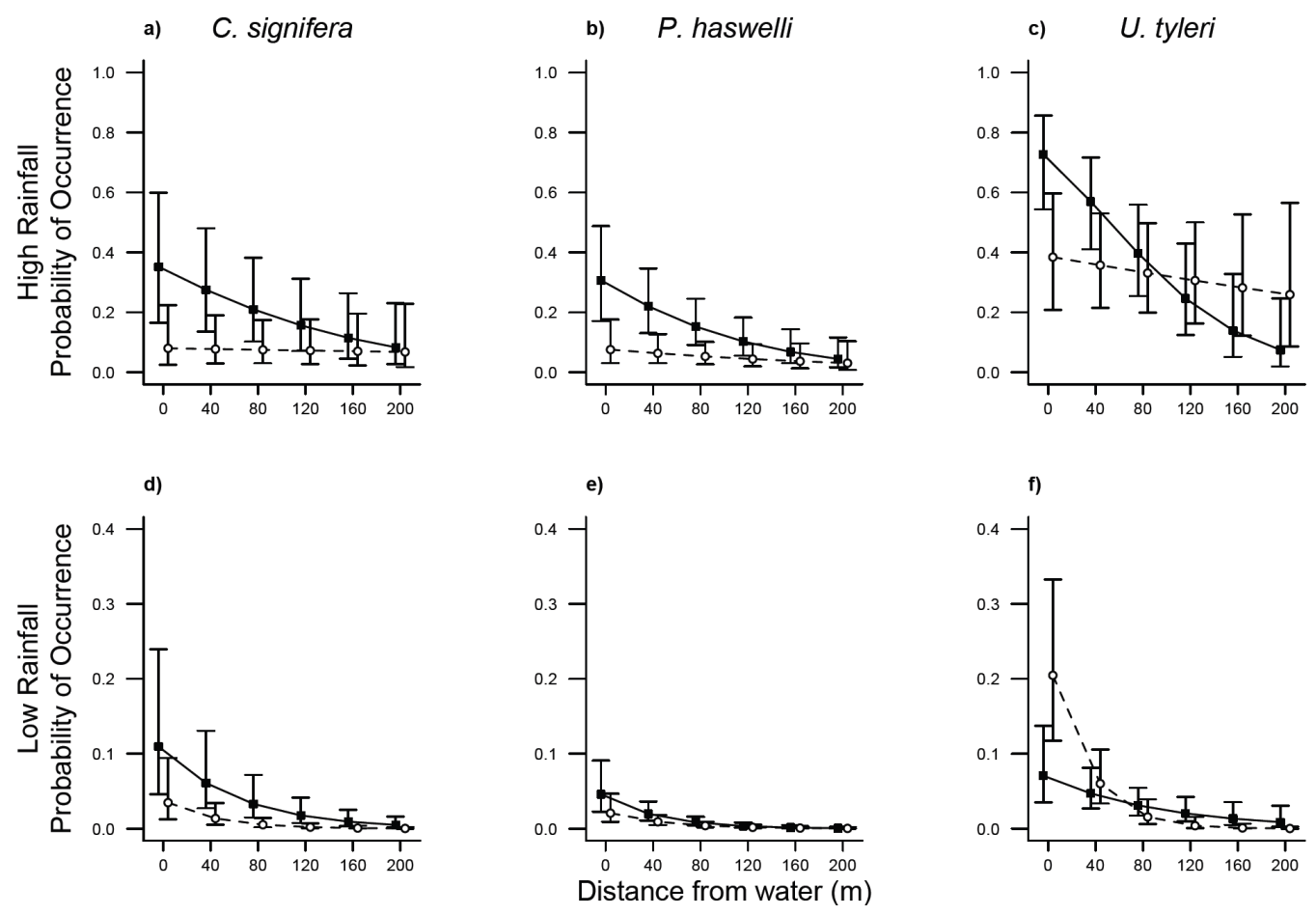


\section{Appendix}

Fig. A.1: Tibia length (TL) versus Snout-Vent length (SVL) for the three most abundant species in our study. Dashed lines give 'cut-off' SVL's used to differentiate adults from juveniles in this study.
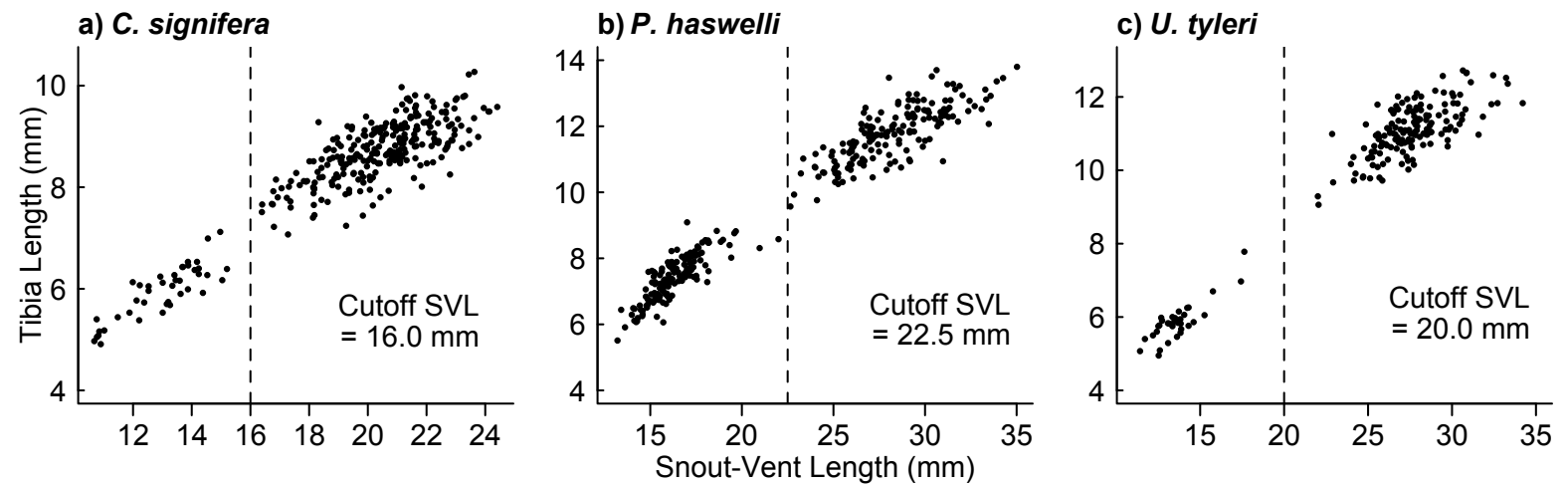